DOI: $10.47743 /$ jss-2021-67-4-23

\title{
Dreptul Algoritmic
}

\author{
Algorithmic Law
}

\author{
Silvia Uscov ${ }^{1}$
}

Rezumat: Dreptul este un set de reguli de convieţuire socială, aşa încât este firesc să ne putem întrebarea dacă normele juridice pot fi „traduse” într-un limbaj de programare care să ofere soluţia algoritmică la o problemă juridică. „Dacă” răspunsul este pozitiv, „atunci” care sunt limitele acestei noi posibilităţi, evaluând potenţialele riscuri pe care le implică o astfel de operaţiune. Dreptul Algoritmic este o noţiune-umbrelă care defineşte ansamblul normativ creat de un sistem algoritmic, cu intervenţie umană minimă, pe baza datelor din viaţa reală.

Cuvinte-cheie: drept algoritmic; normativ algoritmic; inteligenţă artificială; imperativul cuantic; proces democratic

\begin{abstract}
The law is a set of rules of social coexistence, so it is natural to ask ourselves whether legal rules can be "translated" into a programming language that provides the algorithmic solution to a legal problem. "If" the answer is positive, "then" what are the limits of this new possibility, assessing the potential risks involved in such operation. Algorithmic law is an umbrella notion that defines the normative set created by an algorithmic system, with minimal human intervention, based on real life data. Algorithmic law is an umbrella notion that defines the normative set created by an algorithmic system, with minimal human intervention, based on real life data.
\end{abstract}

Keywords: algorithmic law; algorithmic normative; artificial intelligence; quantum imperative; democratic process

\section{Noţiuni de bază în domeniul inteligenţei artificiale}

Clifford A. Pickover ${ }^{2}$ ilustrează istoria preocupărilor umane ce stau la baza dezvoltării în prezent a inteligenţei artificiale, plecând de la inventarea jocului „X şi 0" (Tic-Tac-Toe) în anul 1.300 î.Hr. şi trecând prin mitologia greacă unde avem o reprezentare a unui automaton, Talos, dar şi prin concepţia lui Aristotel în Politica, „căci dacă oricare dintre unelte, fie la poruncă, fie din presimţire, şi-ar îndeplini lucrul său, precum se spune despre statuile lui Dedal - şi despre trepiedurile lui Hefaistos, despre care poetul zice că «pătrundeau automate în ceata zeilor», dacă

\footnotetext{
${ }^{1}$ Avocat, Baroul București, e-mail: silvia.uscov@uscov.eu.

${ }^{2}$ C.A. Pickover, Artificial Intelligence - An Illustrated History, From Medieval Robots to Neural Networks, Editura Sterling Publishing Co., Inc, New York, 2019.
} 
suveicile ar ţese singure şi plectrul ar cânta singur, patronilor nu le-ar mai trebui lucrători şi nici stăpânilor, sclavi”3,4.

Jeff Krimmel spunea că, în condiţiile în care inteligenţa artificială se defineşte ca orice tehnologie care ajută omul să ducă la îndeplinire o sarcină cognitivă, preluându-i în parte sau în tot această sarcină, atunci totul a început cu calendarul, care ne ajută să nu mai apelăm la memorie pentru calcularea zilelor, săptămânilor, anilor, şi cu abacul, care ne ajută la efectuarea unor calcule complexe ${ }^{5}$.

Probabil că această definiţie este cea mai cuprinzătoare, deoarece arată dorinţa omenirii de a-şi augmenta capacitatea de procesare a informaţiilor, dar, prin raportare la stadiul actual de dezvoltare al tehnologiei informaţiei, care permite ca procesarea unei cantităţi uriaşe de date să fie realizată în mod automat, omului nerevenindu-i decât misiunea de a prelua rezultatul pentru a-l integra în alte procese cognitive, e nevoie de o desprindere a definiţiei de trecut şi de introducerea ei doar în sfera computerizării pentru a avea o reprezentare mai apropiată de realitate a perspectivelor viitorului.

Conform art. 3 pct. 1 din Propunerea pentru un Regulament al Parlamentului European şi al Consiliului de stabilire a unor norme armonizate privind inteligenţa artificială (Legea privind Inteligenţa Artificială) şi de modificare a anumitor acte legislative ale Uniunii (Propunerea de Regulament AI), sistemul de inteligenţă artificială este definit ca un software care este dezvoltat prin una sau mai multe dintre tehnicile şi abordările enumerate în anexa I şi care, pentru un anumit set de obiective definite de om, poate genera rezultate precum conţinuturi, previziuni, recomandări sau decizii care influențează mediile cu care interacționează ${ }^{6}$.

Abordările menţionate în Anexa 1 se referă la Machine Learning (învăţare automată) - supervizat sau nesupervizat - şi Deep Learning (sau alte metode de învăţare aprofundată), dar şi la abordări statistice, estimări bayeziene, metode de căutare şi de optimizare, abordări bazate pe logică şi cunoaştere, inclusiv reprezentarea cunoştinţelor, programare inductivă (logică), baze de cunoştinţe,

${ }^{3}$ Aristotel, Politica, redactor N. Năstase, ediţie actualizează a lucrării Politica apărută la Editura Cultura Naţională în anul 1924, traducere de El. Bezdechi, Editura Biblioteca Centrală Universitara „Lucian Blaga”, p. 8, [Online] la https://www.scribd.com/ doc/25315388/Aristotel-Politica, accesat 22.11.2021.

${ }^{4}$ A se vedea și M. Devecka, Did the Greeks Believe in their Robots?, The Cambridge Classical Journal, Volumul 59, Editura Cambridge University Press, Decembrie 2013, pp. 52 - 69, [Online] la https://www.cambridge.org/core/journals/cambridge-classical-journal/ article/did-the-greeks-believe-in-their-robots/5DBC2382196660C31F8269227B05D883, accesat 22.11.2021.

${ }^{5} \mathrm{~J}$. Krimmel, Artificial Intelligence Started with the Calendar and Abacus, 2017, [Online] la https://web.archive.org/web/20171122023732/http://www.stemtobusiness.com/artificialintelligence-started-with-the-calendar-and-abacus, accesat 22.11.2021.

${ }^{6}$ Propunerea pentru un Regulament al Parlamentului European şi al Consiliului de stabilire a unor norme armonizate privind inteligența artificială (Legea privind Inteligența Artificială) și de modificare a anumitor acte legislative ale Uniunii, COM/2021/206 final, Bruxelles, 21.04.2021, [Online] la https://eur-lex.europa.eu/legal-content/EN/TXT/?qid= 1623335154975\&uri=CELEX\%3A52021PC0206, accesat 24.11.2021. 
motoare inductive şi deductive, sisteme de raţionament (simbolic) şi de expertiză (reasoning and expert systems).

Aceste tehnici permit unui sistem AI să înveţe cum să atingă anumite scopuri stabilite de operator (coder), în cadrul cărora se cunoaşte că problemele cu care se va confrunta sistemul pentru atingerea acestor scopuri nu pot fi precis definite, presupunând analize interconectate ale căror metode nu pot descrise prin reguli de raţionament simbolic şi fiind este necesar să i se acorde sistemului o libertate mai mare de mişcare sau, am putea spune, de „gândire”.

„Inteligenţa artificială (AI) se referă la sistemele concepute de oameni care, în urma stabilirii unui scop complex, acţionează în lumea fizică sau digitală prin perceperea mediului lor, interpretarea datelor structurate sau nestructurate colectate, formarea raţionamentului pe baza cunoştinţelor derivate din aceste date şi fundamentarea deciziilor celor mai adecvate privind măsurile de întreprins (conform parametrilor predefiniţi) pentru atingerea scopului dat. Sistemele AI pot fi, de asemenea, proiectate pentru a învăţa să-şi adapteze comportamentul, analizând modul în care mediul este afectat de acţiunile lor anterioare.

Ca disciplină ştiinţifică, AI include mai multe abordări şi tehnici, cum ar fi Machine Learning (din care Deep Learning şi Reinforcement Learning - învăţare consolidată - sunt exemple specifice), raţionamentul automat (care include planificarea, programarea, reprezentarea şi raţionalizarea cunoştinţelor, căutarea şi optimizarea) şi robotică (care include controlul, percepţia, senzorii şi actuatorii, precum şi integrarea tuturor celorlalte tehnici în sistemele cyber-fizice)"”.

Pentru a se înţelege relaţia de la întreg la parte între sistemele descrise mai sus, apelăm la următoarea reprezentare grafică:

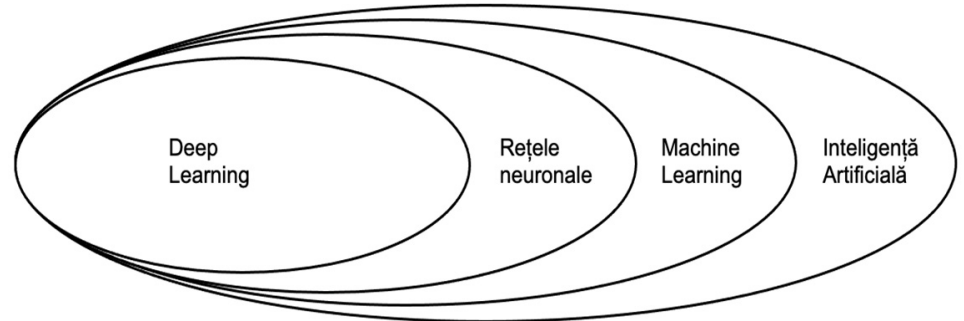

Fig. 1. Matryoshka - De la inteligenţă artificială la deep learning ${ }^{8}$

Acestea nu ar putea fi posibile în lipsa Big Data, care, în concepţia profesorului Ana Nordberg, „nu sunt doar seturi de date statice, printre altele, se

${ }^{7}$ Comisia Europeană, Directoratul General pentru Comunicare, High-Level Expert Group on Artificial Intelligence, A definition of AI: Main capabilities and scientific disciplines, Comisia Europeană, B-1049 Bruxelles, 18.12.2018, [Online] la https://ec.europa.eu/ futurium/en/system/files/ged/ai_hleg_definition_of_ai_18_december_1.pdf, accesat 25.11.2021.

${ }^{8}$ A se vedea [Online] https://apmonitor.com/do/index.php/Main/DeepLearning, accesat 25.11.2021 
caracterizează prin faptul că sunt date eterogene în timp real, aflate în actualizare constantă şi, de asemenea, capabile să genereze în mod continuu date noi. (...) Noţiunea de Big Data este de obicei asociată şi caracterizată prin prezenţa celor «4V» - volum, viteză, varietate şi veridicitate. Volumul, se referă la un volum exploziv de date produse din diferite surse: internetul lucrurilor (n.a. IoT), reţelele sociale, aplicaţiile, senzori, rețele interne (de ex. sisteme de facturare, urmărire a mărfurilor în tranzit şi a livrărilor clienţilor); depozite de informaţii (de exemplu, baze de date, biblioteci, depozite ştiinţifice şi bio-bănci); informaţia din sectorul public etc. Viteza se referă la natura dinamică a datelor mari. Informaţiile sunt procesate în timp real şi accesate în timp ce noi date sunt produse în mod constant. Varietate, se referă la faptul că datele mari sunt date din mai multe surse, în diverse tipuri şi formate (de exemplu, imagini, texte, audio, video, comunicare nonverbală, cum ar fi emoji, meme, hashtag-uri, etichete, aprecieri, glisări, localizare geografică, timp, etc). Veridicitatea, corespunde nevoii ca informaţia (informaţie semantică) să fie corectă (cel puţin în lumina stadiului tehnicii). Nu toate Big Data vor cuprinde acest ultim element. Veridicitatea este un aspect căruia informaticienii îi acordă o atenţie considerabilă, în special în aplicaţiile de luare a deciziilor asistate sau automatizate (de exemplu, în sectorul judiciar sau al sănătăţii), dar şi în industria de automatizare şi auto (de exemplu, robotică şi vehicule făă şofer). Afirmarea veridicităţii datelor sursă şi de instruire necesită un control strict asupra originii acestora şi exclude multe surse de date. Nu numai că este dificil să se afirme veridicitatea datelor sursă, dar veridicitatea joacă un rol în extragerea datelor (n.a. data mining), şi în deducţiile (n.a. inference) pe baza datelor în machine learning. Acest tip de produs de date poate fi extrem de util în materializarea unei varietăţi de procese de luare a deciziilor, dar veridicitatea sa este extrem de dificil sau durează mult pentru a fi confirmată manual de către om. (...) Pe scurt, Big Data corespunde agregării marilor seturi de date, prelucrate prin mijloace computerizate" .

Prin urmare, aşa cum putem observa, problema în ceea ce priveşte Big Data nu este legată de volum, viteză sau varietate datelor, ci de calitatea acestor date, respectiv cât de corecte (veridice) sunt ele, lucru important nu numai în prima etapă, de extragere şi introducere în sistem a acestor date, ci şi de instruire în procesele de machine-learning care generează, la rândul lor, modele (acele „inferences").

De interes pentru analiza noastră, prin raportare la complexitatea scopului de atins, respectiv posibilitatea algoritmică de a elabora norme juridice, sunt mai degrabă următoarele sisteme: machine learning şi deep learning.

${ }^{9}$ A. Nordberg, Trade Secret Protection for AI and Big Data: an oxymoron?, în J. Schovsbo, T. Minssen, T. Riis (eds.), The Harmonization and Protection of Trade Secrets in the EU: An Appraisal of the EU Directive, Edward Elgar Publishing, 2020, [Online] la https://portal.research.lu.se/portal/files/98797164/Nordberg_Trade_Secrets_Big_data_and _AI_Innovation_version_of_record_before_EE_editing.pdf, accesat 24.11.2021 (traducerea și interpretarea autorului). 


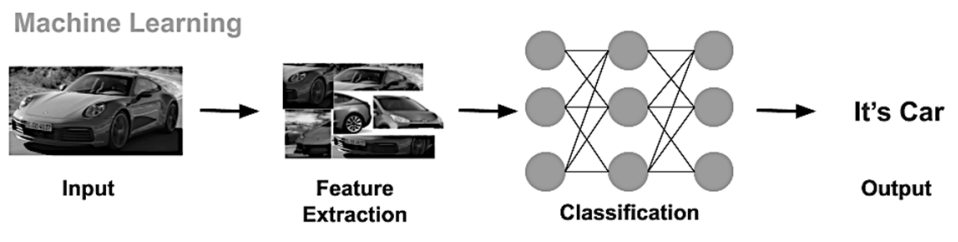

\section{Deep Learning}

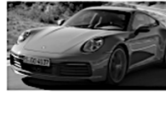

Input

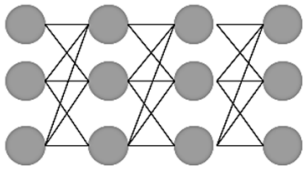

Feature Extraction and Classification
It's Car

Output

Fig. 2. Pictogramă: Machine Learning vs. Deep Learning ${ }^{10}$

\begin{tabular}{|c|c|}
\hline & $g(\mathrm{DL})$ \\
\hline $\begin{array}{l}\text { Modalitatea concretă este prin metoda } \\
\text { „divide et impera", adică se împarte } \\
\text { problema complexă în mai multe probleme } \\
\text { simple, care se rezolvă separat, iar la final se } \\
\text { combină rezultatele pentru a se obține } \\
\text { rezultatul final. }\end{array}$ & $\begin{array}{l}\text { Modalitatea concretă este a rezolva problema } \\
\text { complexă ducând-o până la capăt (end-to- } \\
\text { end), mai întâi prin identificarea tiparelor } \\
\text { simple pe baza cărora se pot identifica } \\
\text { tiparele complexe. }\end{array}$ \\
\hline $\begin{array}{l}\text { Sistemul ia decizia singur pe baza } \\
\text { experiențelor anterioare din faza de instruire. } \\
\text { Regulile în baza cărora va funcționa } \\
\text { raționamentul sunt stabilite de către } \\
\text { operatorul uman astfel încât decizia } \\
\text { (rezultatul final) poate fi uşor de înțeles de } \\
\text { către om. }\end{array}$ & $\begin{array}{l}\text { Sistemul ia decizia pe baza rețelelor } \\
\text { neuronale artificiale cu multe straturi } \\
\text { ascunse, ce imită modalitatea de funcționare } \\
\text { a creierului uman, respectiv comunicarea } \\
\text { între neuroni prin sinapse. Este } 0 \\
\text { subcategorie a ML care își stabilește singur } \\
\text { regulile de raționament astfel încât decizia } \\
\text { (rezultatul final) nu poate fi ușor sau chiar } \\
\text { deloc de înteles de către om. }\end{array}$ \\
\hline $\begin{array}{l}\text { Categoriile de caracteristici distinctive pentru } \\
\text { identificarea tiparelor sunt de obicei codate } \\
\text { manual de operator (coder), astfel încât faza } \\
\text { de instruire durează mai puțin decât faza de } \\
\text { testare. }\end{array}$ & $\begin{array}{l}\text { Categoriile de caracteristici distinctive pentru } \\
\text { identificarea tiparelor sunt descoperite de } \\
\text { către sistem pornind de la cele mai simple } \\
\text { până la cele mai complexe, astfel încât faza } \\
\text { de instruire durează mai mult decât faza de } \\
\text { testare. }\end{array}$ \\
\hline $\begin{array}{l}\text { Poate f1 realizata \$̧1 pe comp } \\
\text { capacitate de procesare normală. }\end{array}$ & lizată numai ne comnut \\
\hline Date putine, dar structurate & Liar și nestructurate \\
\hline Acur & \\
\hline
\end{tabular}

Fig. 3. Diferenţe: Machine Learning vs. Deep Learning ${ }^{11}$

${ }^{10}$ Machine Learning vs. Deep Learning: What is the Difference, [Online] la https:/www.smlease.com/entries/technology/machine-learning-vs-deep-learning-whatis-the-difference-between-ml-and-dl/, accesat 25.11.2021.

${ }^{11}$ A se vedea D. Garg, S. Khan, M. Alam, Integrative Use of IoT and Deep Learning for Agricultural Applications. în P. K. Singh et al. (Eds.): Proceedings of ICETIT 2019, LNEE 605, 2020, pp. 521-531, [Online] la https://www.researchgate.net/publication/336000398_ Integrative_Use_of_IoT_and_Deep_Learning_for_Agricultural_Applications, accesat 25.11.2021. 
$\mathrm{Cu}$ cât DL are mai multe straturi ascunse, evident, nivelul de abstractizare a informaţiilor din date creşte, putându-se realiza operaţiuni din ce în ce mai complexe.

Problema care se pune constant este înţelegerea mecanismului de determinare a categoriilor de caracteristici distinctive care se regăseşte în straturi ascunse (,hidden layers”) şi care conduce la apariţia fenomenului de opacizare, respectiv „black box”, în contradicţie cu principiul transparenţei şi al explicabilităţii (din eng. „explainability”) ce ar trebui să guverneze orice mecanism cu impact asupra mediului înconjurător, inclusiv asupra drepturilor şi libertăţilor oamenilor. Dacă ar fi să asemănăm cu modul uman de ajungere la un rezultat, cel mai probabil black box-ul ar fi o formă de intuiţie umană.

Aşa cum deciziile care pot influenţa drepturile şi libertăţile oamenilor nu se pot baza doar pe intuiţie, mai ales în contextul unor decizii majore, aşa nu este admisibil nici ca un sistem AI să genereze un rezultat al cărui raţionament nu poate fi explicabil.

Cele 4 principii ale explicabilităţii AI sunt:

„(1) Explanation (explicare): sistemele furnizează dovezi însoţitoare sau motiv(e) pentru toate rezultatele.

(2) Meaningful (sens): sistemele oferă explicaţii care sunt pe înţelesul utilizatorilor individuali.

(3) Explanation Accuracy (acurateţea explicaţiei): explicaţia reflectă corect procesul sistemului de generare a rezultatului.

(4) Knowledge Limits (limitele cunoaşterii): sistemul funcţionează numai în condiţiile pentru care a fost proiectat sau când sistemul atinge o încredere suficientă în rezultatul său"12.

Fosca Giannotti, cercetător principal la Institutul de Ştiinţe şi Tehnologie a Informaţiei al Consiliului Naţional de Cercetare din Pisa, Italia, a primit un grant de 2,5 milioane EUR din partea UE pentru a dezvolta până la 30.09.2024 un sistem care să înlăture sau să diminueze problema opacităţii sistemelor AI cu multe straturi ascunse prin determinarea explicaţiilor cauzale, adică tipare care surprind relaţiile cauzale între caracteristici şi decizie, dar şi explicaţii din mecanismul de generare a datelor acestor sisteme complexe ${ }^{13}$.

Dacă reunim cele două probleme, respectiv calitatea precară a datelor cu care este alimentat sistemul AI şi opacitatea acestuia, atunci putem asista la un bias (subiectivism/ preconcepţie) sistemic, determinat de creşterea exponenţială influenţelor negative asupra rezultatului.

12 P.J. Phillips, C.A. Hahn, P.C. Fontana, D.A. Broniatowski, M.A. Przybocki, Four Principles of Explainable Artificial Intelligence, National Institute of Standards and Technology și U.S. Department of Commerce August 2020, https://doi.org/10.6028/ NIST.IR.8312-draft, accesat 26.11.2021.

${ }^{13}$ A se vedea Proiectul XAI - Science and technology for the explanation of AI decision making, [Online] la https://cordis.europa.eu/project/id/834756, accesat 25.11.2021. 


\section{Posibilitatea normativului algoritmic}

Preocuparea de codificare a legislaţiei într-o manieră care să excludă sau să limiteze drastic intervenţia umană a fost dezvoltată de Jeremy Bentham, autorul Raymond Wacks reţinând în legătură cu filosofia lui Bentham următoarele: „Haosul din common law trebuia să fie tratat sistematic. Pentru Bentham, aceasta consta, pur şi simplu, în codificare. Codurile juridice ar diminua semnificativ puterea judecătorilor; sarcina lor ar consta mai puţin în interpretarea decât în administrarea legii. De asemenea, ar elimina o mare parte din nevoia de avocaţi: codul ar fi uşor de înţeles fără ajutorul consilierilor juridici" ${ }^{14}$. Chiar dacă Napoleon a realizat codificarea legislaţiei, acest lucru nu a atins perfecţiunea pe care o viza Bentham, ci a fost mai degrabă o activitate de sistematizare.

Filosofia lui Bentham venea în urma ideii matematicianului şi filosofului Gottfried Wilhelm Leibniz, care considera că aplicarea legii nu ar trebui să genereze rezultate contradictorii atâta timp cât legea este interpretată corect. Prin urmare, este nevoie de introducerea unor reguli de interpretare, care, prin aplicarea de către oricine (sau orice, mai nou), să genereze acelaşi rezultat. El avea această concepţie nu numai cu privire la lege, dar o extindea şi la morală, ca factor care generează şi influenţează puternic legea.

René Descartes considera că există „adevărul universal”, la care se poate ajunge folosind raţiunea deoarece toate fenomenele sunt explicabile pe deplin atunci când principiile care le guvernează sunt înţelese, acesta fiind motivul pentru care Leibniz considera că mecanismul limbajului şi al cogniţiei pot fi şi ele pe deplin înţelese.

În Călătoriile lui Guliver (1726), autorul Jonathan Swift ironizează ideea lui Leibniz în scena vizitei la Marea Academie din Lagado unde se regăsea „motorul”, o maşinărie din lemn cu multe fire pe care sunt mici cuburi de lemn cu simboluri scrise pe fiecare parte. Studenţii Academiei apăsau pe mânerele maşinăriei, determinând cuburile să se rotească şi să afişeze noi combinaţii, după care scriau rezultatul pe o hârtie şi îl înmânau profesorului. În acest fel, profesorul spunea că el şi studenţii pot scrie în mod creativ orice fără cel mai mic ajutor din partea geniului sau a studiului. De fapt, Swift voia să arate că limbajul nu este un sistem formalist care oglindeşte raţionamentul, aşa cum susţinea Leibniz, ci este o formă de exprimare ambiguă care capătă sens doar în contextul folosit, astfel încât este necesar nu doar să ai un set de reguli, ci şi capacitatea necesară de a înţelege adevăratul sens al cuvintelor, contextualizarea ${ }^{15}$.

Dreptul Algoritmic este o noţiune umbrelă, care acoperă ansamblul normelor juridice create prin intermediul sistemelor AI, devenind ceea ce am putea

\footnotetext{
${ }^{14}$ R. Wacks, Philosophy of Law, A Very Short Introduction, Ediția a II-a, Editura Oxford University Press, 2014, p. 27.

${ }^{15} \mathrm{O}$. Schwartz, In the 17th Century, Leibniz Dreamed of a Machine That Could Calculate Ideas The machine would use an "alphabet of human thoughts" and rules to combine them, 04.11.2019, [Online] la https://spectrum.ieee.org/in-the-17th-century-leibniz-dreamed-ofa-machine-that-could-calculate-ideas, accesat 25.11.2021.
} 
numi ca fiind normativul algoritmic. Acesta poate fi expresia unei sistematizări statistice, a unei prelucrări algoritmice, predictive a situaţiilor din viaţa reală, pe principiul ,if/then” (trad. „dacă/atunci”), ajungând până la abordări de tipul Deep Learning.

Bineînţeles, scopul prelucrărilor de date ar trebui să beneficieze de intervenţie umană, dar setul de date este aproape nelimitat, la fel şi posibilităţile de configurare.

Cel mai simplu mecanism s-ar baza doar pe sistematizare statistică şi un exemplu din viaţa reală ar fi măsurile restrictive din timpul pandemiei care se bazează pe ratele de incidenţă, ale infectărilor precum şi ale deceselor celor afectaţi de pandemia de Covid-19.

Simplist descris, dacă (IF) rata de incidenţă este sub/peste o anumită valoare, atunci (THEN) se iau anumite măsuri restrictive sau nu.

De asemenea, se pot gândi şi sisteme mai complexe, măsurile restrictive care se iau putând fi determinate pe baza statisticilor de focare, dar şi într-o abordare de tipul Deep Learning, prin preluarea informaţiilor prelucrate direct din dosarele medicale şi a ratei de incidenţă a contravenţiilor sau infracţiunilor într-un areal.

În acest fel, cantitatea de date şi interpretarea lor ar putea să înlocuiască expunerea de motive/notele de fundamentare ale actelor normative şi, eventual ipoteza normei, iar ulterior, nu omul să fie cel care creează instrucţiunea (dispozitivul şi sancţiunea normei), ci algoritmul însuşi.

Bineînţeles, putem extinde acest exemplu la orice domeniu al dreptului clasic.

Regulamentul (UE) 2016/679 al Parlamentului European şi al Consiliului din 27 aprilie 2016 privind protecţia persoanelor fizice în ceea ce priveşte prelucrarea datelor cu caracter personal şi privind libera circulaţie a acestor date şi de abrogare a Directivei 95/46/CE (Regulamentul general privind protecţia datelor) ${ }^{16}$ (GDPR) prevede în preambul faptul că persoana vizată ar trebui să aibă dreptul de a nu face obiectul unei decizii, care poate include o măsură, care evaluează aspecte personale referitoare la persoana vizată, care se bazează exclusiv pe prelucrarea automată şi care produce efecte juridice care privesc persoana vizată sau o afectează în mod similar într-o măsură semnificativă (pct. 71), dar, conform art. 22 alin. (2) lit. b), dreptul de a nu face obiectul unui proces decizional individual automatizat nu se recunoaşte atunci când decizia este autorizată prin dreptul Uniunii sau dreptul intern care se aplică operatorului şi care prevede, de asemenea, măsuri corespunzătoare pentru protejarea drepturilor, libertăţilor şi intereselor legitime ale persoanei vizate.

Dacă ne referim la situaţia normativului algoritmic, atunci există posibilitatea legală a implementării sale, apreciind totodată că se încadrează în noţiunea de

${ }^{16}$ Regulamentul (UE) 2016/679 al Parlamentului European și al Consiliului din 27 aprilie 2016 privind protecția persoanelor fizice în ceea ce privește prelucrarea datelor cu caracter personal și privind libera circulație a acestor date și de abrogare a Directivei 95/46/CE (Regulamentul general privind protecția datelor), JO L 119, 4.5.2016, p. 1-88, [Online] forma consolidată la 04.05 .2016 la https://eur-lex.europa.eu/legal-content/RO/TXT/?qid= 1532348683434\&uri=CELEX\%3A02016R0679-20160504, accesat 25.11.2021. 
procese decizionale individuale, chiar dacă norma juridică din sistemul clasic este impersonală.

Prin raportare la art. 6 alin. (2) din Propunerea de Regulament AI, sistemul de inteligenţă artificială care permite conceperea unor norme juridice s-ar putea încadra la sisteme cu grad de risc ridicat. De aceea este necesar să analizăm mai departe riscurile inerente pentru drepturile şi libertăţile fundamentale, precum şi pentru ordinea de drept democratică.

\section{Calitatea normativului algoritmic şi riscul sistemic asupra principiilor democratice}

Orice schimbare nu trebuie să fie doar posibilă, ci şi să aducă o contribuţie benefică pentru progresul omenirii.

Referindu-ne la legislaţie, deşi există posibilitatea teoretică a creării ei prin intermediul sistemelor AI, aceasta trebuie să asigure respectarea unui principiu esenţial pentru păstrarea încrederii în sistemul normativ şi asigurarea calităţii lui, principiul securităţii juridice. Numai astfel se aduce o contribuţie benefică celor care sunt subiectele ordinii de drept.

Principiul securităţii juridice a fost definit cel mai bine în doctrină ca reprezentând esenţa faptului că oamenii trebuie protejaţi „,contra unui pericol care vine chiar din partea dreptului, contra unei insecurităţi pe care a creat-o dreptul sau pe care acesta riscă s-o creeze"17.

Pe baza sistemului normativ clasic s-a dezvoltat o bogată jurisprudenţă care defineşte condiţiile de calitate ale unei norme, respectiv: accesibilitate, claritate şi previzibilitate.

Pentru ca norma să fie adaptabilă oricăror împrejurări, ea este redactată în termeni generali şi impersonali, fără a depăşi limitele menţionate mai sus, urmând ca cel care o aplică să o interpreteze şi să o raporteze la o situaţie concretă. Am putea descrie această procedură de legiferare ca fiind una de tip „open box”, spre deosebire de metoda pe care ar presupune-o utilizarea unui algoritm (,closed box”), o metodă ce ar defini toate situaţiile posibile, le-ar încadra şi le-ar reglementa în detaliu, fără posibilitatea interpretării.

$\mathrm{Cu}$ toate acestea, este dificil să ne imaginăm cum ar putea algoritmul să depăşească barierele limbajului natural uman, pe cât de complex, pe atât de frumos, chiar şi în condiţiile în care algoritmii actuali reuşesc să îl proceseze cu acurateţe din ce în ce mai mare, dar doar ca pe o copie fidelă, fără capacitatea de a-i înţelege raţiunile.

${ }^{17} \mathrm{~L}$. François, Le problème de la sécurité juridique, lucrarea La sécurité juridique, Editura Jeune Barreau de Liège, Liège, 1993, p. 10, apud. C.F. Costaş, Principiul securitatii juridice, [Online] la https://www.fiscalitatea.ro/principiul-securitatii-juridice-342/, accesat 21.11.2021. 
Această orientare a fost descrisă ca pozitivism ştiinţific, „modalitatea carteziană de a privi lumea, într-o cheie strict tehnică, matematică, rece, nu caldă" ${ }^{\prime 18}$, deşi „spaţiul umanităţii este un spaţiu al fenomenelor, adică al trăirilor, nu al calculelor, al ordonării matematice" 19 .

Teoretic ne putem imagina o normă de drept care, în calitate de premisă majoră a silogismului juridic, să epuizeze toate ipotezele care s-ar putea ivi în viaţa reală ca premise minore ale acestuia, permiţând aplicarea legii fără intervenţia omului, ci doar prin recurgere la AI. Întrebarea este cum ar mai putea înţelege subiectul de drept o asemenea normă pentru a se conforma ei? Aceasta ar fi asemenea unei armuri care se mulează perfect pe trupul cavalerului, respectiv pe corpul social, întrucât este construită din foarte multe piese, dar printr-o atare construcţie armura ar deveni atât de grea încât cel ce o îmbracă nu s-ar mai putea mişca, putând fi chiar strivit sub povara ei. Dreptul algoritmic ar fi astfel izvor de securitate, dar o securitate care blochează circuitul juridic şi astfel, progresul. Dintr-o atare perspectivă s-a susţinut că „cu cât dreptul atinge prin fermitatea conceptelor scopul de securitate care îi este propriu, cu atât mai mult riscă să se depărteze de scopul ce-i este comun cu morala: justiţia. O regulă juridică riscă să violeze justiţia cu atât mai puţin cu cât supleţea formulei sale îi permite o mai exactă adaptare la cazul particular; dar atunci ea oferă cu atât mai puţină securitate" 20 .

Nevoia inconturnabilă de a realiza echilibrul între drept şi justiţie, între fermitate şi flexibilitate, între previzibil şi imprevizibil, între stabilitate şi dinamism, precum şi între securitate şi progres, a condus la introducerea în ansamblul normativ a „standardelor juridice nedeterminate” care completează înţelesul literal al normei (factor de completare) sau îl corectează (factor de corectare) în funcţie de aprecierea situaţiilor concrete cărora ea ar trebui să i se aplice, şi care acţionează ca „instrument de calificare” a conduitei subiectului de drept sau ca „instrument de diferenţiere" între subiectele de drept şi conduitele acestora. Aceste standarde pătrund în golurile dintre dispoziţiile cu caracter tehnic, astfel încât să îi asigure dreptului vocaţia integratoare pentru întreg universul infinit al raporturilor sociale, asigurând cu fineţe, în situaţii altminteri de neanticipat, ca fiecare să primească ceea ce i se cuvine (suum cuique tribuere) şi nimănui să nu i se încalce drepturile (alterum non laedere), în acord cu ideea de echilibru ca principiu economic, precum şi ca toţi să trăiască potrivit regulilor binelui şi echitabilului (honeste vivere), ca principiu psiho-moral ${ }^{21}$. Dreptul algoritmic nu se poate dispensa de asemenea

${ }^{18}$ G. Colang, Fundamentele filosofice ale comunicării, Editura Mustang, București, 2018, p. 127, [Online] la http://www.georgecolang.ro/wp-content/uploads/2021/04/GeorgeColang-Fundamentele-filosofice-ale-comunicarii.-1-Mustang-2018-.pdf, accesat 26.11.2021.

${ }^{19}$ Ibidem.

${ }^{20} \mathrm{G}$. Renard, Le proces $d u$ conceptualisme juridique, în vol. Le Droit, la Logique et le Bon Sens, Paris, 1946, p. 79, apud. (citat de) A. Severin, Elemente fundamentale de drept al comerțului internațional, Editura Lumina lex, București, 2004, p. 47.

${ }^{21}$ A.M. Naschitz, Teorie și tehnică în procesul de creare a dreptului, București, 1969, p. 126, apud. A.Severin, Elemente fundamentale de drept al comerțului internațional, Editura 
standarde al căror conţinut este determinabil numai în concret şi numai prin evaluarea nuanţată a realităţii din momentul aplicării legii, ceea ce impune recurgerea la inteligenţa umană.

Spre exemplu, conceptul de „bună credinţă” este o valoare juridică fundamentală, care exprimă intima convingere a unei persoane că ceea ce face este bine, în acord nu numai cu legea, dar şi cu morala, sancţionându-se comportamentele abuzive. Fiind legat de o dimensiune intrinsecă fiinţei umane, de o atitudine subiectivă cu privire la un fenomen, acesta nu poate fi copiat. Subiectivismul nu poate fi raţionalizat, el se află în colţul opus obiectivismului.

Dacă ar fi să renunţăm la subiectivism în relaţia cu norma juridică, atunci ar însemna să considerăm că însăşi fiinţa umană este o entitate pur raţională, în schimb, tocmai îmbinarea armonioasă a obiectivismului raţional cu subiectivismul reprezintă semnul distinctiv al chiar formei noastre de inteligenţă, prin comparaţie cu inteligenţa artificială. Conştiinţa umană ne oferă însăşi individualitatea subiectivă, ceea ce stă la baza drepturilor şi libertăţilor noastre fundamentale individuale.

Prin urmare, riscul major identificat se referă la pierderea reperelor individualităţii umane, la reconfigurarea drepturilor şi libertăţilor fundamentale pe care ar urma să le aşezăm pe un pilon colectiv, în desconsiderarea unicităţii fiinţei umane. Ar însemna ca nu algoritmii să înveţe să fie copii fidele ale umanităţii, ci umanitatea să încerce să devină o copie fidelă a algoritmilor, lucru, evident, absurd.

În plus, intervine şi imprecizia retroactivă (,retroactive vagueness”), adică nu te poţi raporta la o situaţie cu potenţial în viitorul imprevizibil pentru a-i acoperi în mod categoric şi definitiv toate ipotezele. Nici măcar încercările de construire a tuturor ipotezelor de lucru viitoare pe baza jurisprudenţei, ca sursă de drept, nu poate fi considerată ca acoperind varietatea raporturilor juridice şi modul în care le-am putea interpreta, deşi au existat încercări în acest sens prin construirea sistemului HYPO, ce încerca să modifice situaţiile din cazurile soluţionate în instanţe pentru a testa noi posibilităţi de interpretare a legii, şi apoi CABARET, care se folosea de sistemul anterior pentru un sistem hibrid ce încorpora analiza bazată de jurisprudenţă cu analiza bazată pe raţionamentul juridic ${ }^{22}$.

Pe de altă parte, în Cartea Albă privind Inteligenţa artificială - O abordare europeană axată pe excelenţă şi încredere, Comisia Europeană atrage atenţia că inteligenţa artificială ,implică o serie de riscuri potenţiale, cum ar fi un proces decizional opac, discriminarea de gen sau de alt tip, intruziunea în viaţa noastră privată sau utilizarea în scopuri infracţionale"23.

Lumina lex, București, 2004, p. 43; A se vedea și Buna credință, în I.R. Urs, M. Duțu, A. Severin, S. Angheni, S. Neculaescu (coord.), Enciclopedia Juridică Română, vol. I, Editura Academiei Române și Editura Universul Juridic, București, 2018, p. 487 și urm.

${ }_{22}$ M.A. Livermore, Rule by Rules, Computational Legal Studies: The Promise and Challenge of Data-Driven Legal Research (Ryan Whalen, ed.) (2019 Forthcoming), 13 mai 2019, [Online] la https://papers.ssrn.com/sol3/papers.cfm?abstract_id=3387701, accesat 26.11.2021.

${ }^{23}$ Comisia Europeană, Cartea albă privind Inteligenţa artificială - O abordare europeană axată pe excelenţă şi încredere - COM (2020) 65 final, Comisia Europeană, Bruxelles, 
Nu în ultimul rând, trebuie să privim şi la resursele materiale pe care le avem la dispoziţie pentru a realiza un astfel de deziderat, normativul algoritmic. Pentru a putea procesa o cantitate atât de mare de date într-un timp relativ scurt, este nevoie să fie utilizate computerele cuantice, o super-tehnologie destul de nouă şi în continuă dezvoltare, extrem de scumpă şi la care au acces foarte puţini (UE, SUA, China, Germania, Franţa, Marea Britanie, iar dintre privaţi, IBM, Google, Microsoft, Alibaba, Baidu, Tencent ${ }^{24}$ ).

Acest aspect este tratat pe larg de profesorul Valentin Jeutner în lucrarea sa referitoare la dimensiunile juridice ale computerelor cuantice ${ }^{25}$, şi în care introduce imperativul cuantic reflectat în 3 reguli de care atât cei care stabilesc reglementările în domeniu, cât şi cei care dezvoltă computerele cuantice trebuie să ţină seama: (1) acestea să nu creeze sau să exacerbeze inechităţile existente (în special între statele care deţin tehnologia şi cele care nu o deţin); (2) să nu submineze autonomia individuală; (3) să nu se dezvolte soluţii fără a-i consulta pe cei ale căror interese sunt afectate (mai ales în sectorul public, ceea ce înseamnă că inclusiv în ceea ce face obiectul studiului, Dreptul Algoritmic).

Într-o democraţie puterea politică este expresia voinţei poporului, normele juridice fiind o expresie indirectă a voinţei majorităţii. Dar oare însăşi voinţa poporului nu poate fi manipulată printr-o serie de factori astfel încât voinţa reală să fie alterată până la obţinerea unei voinţe contrare celei care ar fi fost obţinută în condiţii normale? Bineînţeles că da, iar dimensiunea istorică ne-a demonstrat acest lucru, mai ales în vremuri în care avem acces la multă informaţie nefiltrată şi suntem presaţi să luăm decizii rapide pe baza acesteia. Astfel, o minoritate cu suficiente resurse materiale poate să influenţeze procesul democratic.

În măsura în care computerele cuantice nu pot fi dezvoltate decât de anumite state sau de privaţi, atunci aceste state sau aceşti privaţi vor deveni forţele dominante la nivel mondial, impunând propriile viziuni asupra lumii, fără capacitatea reală ca ceilalţi participanţi la viaţa democratică să realizeze acest lucru, această tehnologie devenind un instrument foarte util de control al populaţiilor.

În The Great Delusion, autorul John J. Mearsheimer spune că „politica se referă în esenţă la cine poate scrie regulile care guvernează grupul. Această responsabilitate contează foarte mult pentru că membrii oricărei societăţi au sigur nişte interese aflate în conflict, din moment ce nu vor fi niciodată complet de acord cu privire la principiile de bază. Având în vedere acest fapt de bază al vieţii, oricare dintre facţiunile care scrie şi interpretează regulile poate face acest lucru în moduri

19.02.2020, [Online] la https://ec.europa.eu/info/publications/white-paper-artificialintelligence-european-approach-excellence-and-trust_ro, accesat 24.11.2021, față de care Camera Deputaților a României a adoptat opinia exprimată în Hotărârea nr. 28/08.09.2021, publicată în M. Of. nr. 825/09.09.2020.

${ }^{24}$ A se vedea Who are the main players in the world of quantum computing?, 16.12.2020, [Online] la https://www.inria.fr/en/quantum-computing-main-players, accesat 25.11.2021.

${ }^{25}$ V. Jeutner, The Quantum Imperative: Addressing the Legal Dimension of Quantum Computers, 2021 1(1) Morals \& Machines, pp.52-59, ultima revizuire: 18.10.2021 [Online] la https://papers.ssrn.com/sol3/papers.cfm?abstract_id=3820003, accesat 25.11.2021. 
care să servească interesele sale mai degrabă decât ale rivalilor săi sau să reflecte viziunea sa asupra societăţii, mai degrabă decât a rivalilor săi. Desigur, puterea contează foarte mult pentru a determina ce facţiune câştigă această competiţie. $\mathrm{Cu}$ cât un individ sau o facţiune deţine mai multe resurse, cu atât este mai probabil să controleze instituţiile de guvernare. Pe scurt, într-o lume în care raţiunea nu te duce atât de departe, raportul de putere decide de obicei cine trebuie să scrie şi să aplice regulile"26.

Pe lângă resursele materiale, se mai pun trei probleme.

Una este protejarea acestor super-tehnologii prin brevete de invenţie care fac modificările ulterioare dificil de realizat, deşi ele au încorporate în chiar corpusul lor bias-uri în urma faptului că există o mare posibilitate să fie dezvoltate de echipe care nu reflectă diversitatea umană (spre exemplu, diferenţa semnificativă între femei şi bărbaţi care activează domeniul IT). Ca orice creaţie, şi tehnologia însăşi împrumută caracteristicile celui care o dezvoltă, devenind o reflexie fidelă a acestuia. Aceste bias-uri devin incorporate în produs şi generează, la rândul lor, alterarea rezultatelor.

A doua este legată de faptul că aceste super-tehnologii nu oferă certitudinea rezultatului astfel încât tot echipa care o dezvoltă este cea care stabileşte marja de eroare, iar aceasta poate fi diferită de la stat la stat, de la stat la privat sau între privaţi. În acest fel, aflându-te sub spectrul aceleiaşi tehnologii, poţi avea diferenţe semnificative în rezultate, lucru care ar trebui reglementat.

GDPR adresează această problemă încă din preambul, statuând faptul că, pentru a preveni apariţia unui risc major de eludare, protecţia persoanelor fizice ar trebui să fie neutră din punct de vedere tehnologic şi să nu depindă de tehnologiile utilizate (pct. 15).

Ultima problemă se referă la incapacitatea persoanelor, beneficiare ale deciziilor luate de un sistem AI, să le verifice sau să le conteste, ceea ce generează problema lipsei unei răspunderi din cauze obiective.

Acest lucru a fost remarcat şi de alţi autori care spun că „problemele legate de mecanismele de bună guvernare, responsabilitatea şi răspunderea pentru deciziile automate şi statul de drept necesită atenţia legiuitorului în adaptarea prevederilor legale la această nouă formă de luare a deciziilor. Deşi reglementarea generală privind protecţia datelor din Uniunea Europeană este importantă în recunoaşterea procesului decizional automatizat, majoritatea garanţiilor prevăzute de lege în cadrul procesului administrativ echitabil trebuie să fie prevăzute de legiuitorul naţional. Se sugerează că toate ţările trebuie să îşi revizuiască regulile de proces administrativ echitabil în vederea actualizării acestora cu privire la cerinţele procesului decizional automatizat" 27 .

${ }^{26}$ J. J. Mearsheimer, The Great Delusion: Liberal Dreams and International Realities, Editura Yale University Press, New Haven and London, 2018, p. 21 (traducerea și interpretarea autorului).

${ }^{27}$ M. Suksi, Administrative due process when using automated decision-making in public administration: some notes from a Finnish perspective, Artificial Intelligence Law nr. 29/2021, 
Toate acestea au fost remarcate în anul 2020 şi de Adunarea Parlamentară a Consiliului Europei, care şi-a manifestat îngrijorările faţă de dezvoltarea şi utilizarea inteligenţei artificiale în procesul democratic în următorii termeni:

„Tehnologiile bazate pe inteligenţa artificială au un impact asupra funcţionării instituţiilor şi proceselor democratice, precum şi asupra comportamentului social şi politic al cetăţenilor. Utilizarea acestora poate produce atât efecte benefice, cât şi dăunătoare asupra democraţiei. Într-adevăr, integrarea rapidă a tehnologiilor AI în instrumentele moderne de comunicare şi platformele de social media oferă oportunităţi unice de influenţă direcţionată, personalizată şi adesea neobservată asupra indivizilor şi grupurilor sociale, pe care diferiţi actori politici pot fi tentaţi să le folosească în propriul beneficiu.

Dintr-o perspectivă pozitivă, IA poate fi folosită pentru a îmbunătăţi responsabilitatea şi transparenţa guvernului, pentru a ajuta la combaterea corupţiei şi pentru a produce multe beneficii pentru acţiunea democratică, participarea şi pluralismul, făcând democraţia mai directă, eficientă şi receptivă la nevoile cetăţenilor. Tehnologiile bazate pe inteligenţa artificială pot lărgi spaţiul pentru reprezentarea democratică prin descentralizarea sistemelor informaţionale şi a platformelor de comunicare. AI poate consolida autonomia informaţională pentru cetăţeni, poate îmbunătăţi modul în care aceştia colectează informaţii despre procesele politice şi îi poate ajuta să participe la aceste procese de la distanţă, facilitând exprimarea politică şi oferind canale de feedback cu actorii politici. De asemenea, poate contribui la stabilirea unei mai mari încrederi între stat şi societate şi între cetăţeni înşişi.

$\mathrm{Cu}$ toate acestea, AI poate fi - şi se pare că este - folosită pentru a perturba democraţia prin interferenţa în procesele electorale, targetarea personalizată în domeniul politic, modelarea comportamentului alegătorilor şi manipularea opiniei publice. În plus, inteligenţa artificială se pare că a fost folosită pentru a amplifica răspândirea dezinformării, a „camerelor-ecou” (bulelor), a propagandei şi a discursului instigator la ură, erodând astfel gândirea critică, contribuind la creşterea populismului şi la polarizarea societăţilor democratice" 28 .

\section{Concluzii}

Omul nu este şi nu ar trebui vreodată să reprezinte un mijloc, un instrument al tehnologiei, ci un scop în sine. Atâta timp cât nu considerăm că homo sapiens sapiens este doar o etapă în evoluţia spre o eră a homo technologicus sau chiar a celor care renunţă la orice formă de umanitate, mai avem o şansă să înţelegem că

pp. 87-110, [Online] la https://link.springer.com/article/10.1007/s10506-020-09269-x\#citeas, accesat 25.11.2021.

${ }^{28}$ Rezoluția 2341 (2020), Need for democratic governance of artificial intelligence, Adunarea Parlamentară a Consiliului Europei, 22.10.2020, [Online] la https://pace.coe.int/ pdf/0b472b0ef9de710970a8106e0bbaf0d10fe3b0119e48da83a286ab652d6e66b9/resolution\%2 02341.pdf, accesat 24.11.2021 (traducerea și interpretarea autorului). 
ceea ce ne face umani, expresia fragilităţii noastre, nu este o vulnerabilitate, ci o super-putere.

În acord cu această concepţie este şi modalitatea în care înţelegem să reglementăm raporturile sociale sub aspect juridic între actorii umanităţii, apelând la instrumente specifice care trimit la conştiinţă, la moralitate, şi îndepărtându-ne de ceea ce este calculat, matematic, rece.

Prin urmare, chiar dacă, din punct de vedere tehnic, Dreptul Algoritmic ne oferă facilităţi în ceea priveşte redactarea, interpretarea şi aplicarea normelor de drept, oferta pe care ne-o face trebuie acceptată cu rezerve şi consumată cum granum salis, căci, altminteri, ea nu este decât un fruct otrăvit întrucât rescrie paradigma omului care utilizează instrumentul, transformând omul însuşi într-un instrument aruncat în capcana tehnologiei.

\section{Referinţe}

Aristotel, Politica, Năstase N. (red.), ediţie actualizată a lucrării Politica apărută la editura Cultura Naţională în anul 1924, traducere de El. Bezdechi, Editura Biblioteca Centrală Universitara „Lucian Blaga”

Bostrom N., Superinteligenţa. Direcţii, pericole, strategii, Editura Litera, Bucureşti, 2019

Brockman J., Minţi posibile: douăzeci şi cinci de perspective asupra inteligenței aritificiale, Editura Vellant, București, 2019

Colang G., Fundamentele filosofice ale comunicării, Editura Mustang, Bucureşti, 2018

Coleman F., A Human Algorithm: How Artificial Intelligence is Redefining Who We Are, Editura Counterpoint, Berkeley, California, 2019

Comisia Europeană, Directoratul General pentru Comunicare, High-Level Expert Group on Artificial Intelligence, A definition of AI: Main capabilities and scientific disciplines, Comisia Europeană, B-1049 Bruxelles

Comisia Europeană, Cartea albă privind Inteligența artificială - O abordare europeană axată pe excelenţă şi incredere (Cartea Albă $\operatorname{COM}(2020) 65$ final), Comisia Europeană, Bruxelles, 2020

Costaş C.F., Principiul securităţii juridice, [Online]

Craglia M. (Ed.), Annoni A., Benczur P. Bertoldi P., Delipetrev P., De Prato G., Feijoo C., Fernandez M.E., Gomez E., Iglesias M., Junklewitz H., López Cobo M., Marténs B., Nascimento S., Nativi S., Polvora A., Sanchez I., Tolan S., Tuomi I., Vesnic Alujevic L., Artificial Intelligence - A European Perspective, EUR 29425 EN, Publications Office, Luxembourg, 2018, https://doi.org/10.2760/11251

Devecka M., Did the Greeks Believe in their Robots? în The Cambridge Classical Journal, 59, 2013, https://doi.org/10.1017/S1750270513000079

Garg, D., Khan S., Alam M., Integrative Use of IoT and Deep Learning for Agricultural Applications, în P. K. Singh et al. (Eds.): Proceedings of ICETIT 2019, LNEE 605, 2020, http://dx.doi.org/10.1007/978-3-030-30577-2_46

Jeutner V., The Quantum Imperative: Addressing the Legal Dimension of Quantum Computers vol. 1 (1) Morals \& Machines, 2021

Kaplan J., Artificial Intelligence. What Everybody Needs to Know, Editura Oxford University Press, Marea Britanie, 2016

Krimmel J., Artificial Intelligence Started with the Calendar and Abacus, 2017

Kumar P., Artificial Intelligence: Reshaping Life and Business, Editura BPB Publications, New Delhi, 2019 
Livermore M.A., Rule by Rules, Computational Legal Studies: The Promise and Challenge of Data-Driven Legal Research (Ryan Whalen, ed.), 2019, https://doi.org/10.2139/ ssrn.3387701

Mearsheimer J.J., The Great Delusion: Liberal Dreams and International Realities, Yale University Press, New Haven, 2018

Mitchell M., Artificial intelligence : a guide for thinking humans, Editura Farrar, Straus and Giroux, New York, 2019

Nordberg A., Trade Secret Protection for AI and Big Data: an oxymoron?, în Schovsbo J., Minssen T., Riis T. (eds.), The Harmonization and Protection of Trade Secrets in the EU: An Appraisal of the EU Directive, Edward Elgar Publishing, 2020

Phillips P.J., Hahn C.A., Fontana P.C., Broniatowski D.A., Przybocki M.A., Four Principles of Explainable Artificial Intelligence, National Institute of Standards and Technology şi U.S. Department of Commerce August 2020

Pickover C.A., Artificial Intelligence - An Illustrated History, From Medieval Robots to Neural Networks, Editura Sterling Publishing Co., Inc, New York, 2019, ISBN: 978-1-4549-3359-5

Schwartz O., In the 17th Century, Leibniz Dreamed of a Machine That Could Calculate Ideas The machine would use an ,alphabet of human thoughts” and rules to combine them, 2019

Severin A., Elemente fundamentale de drept al comerţului internaţional, Editura Lumina lex, Bucureşti, 2004

Stănilă L.M., Inteligenţa artificială, dreptul penal şi sistemul de justiţie penală: amintiri despre viitor, Editura Universul Juridic, Bucureşti, 2020

Tegmark M., Viaţa 3.0: Omul în epoca inteligenţei artificiale, Editura Humanitas, Bucureşti, 2019

Suksi M., Administrative due process when using automated decision-making in public administration: some notes from a Finnish perspective. Artificial Intelligence Law 29, 87110 (2021), https://doi.org/10.1007/s10506-020-09269-x

Susskind J., Politica viitorului. Tehnologia digitală şi societatea, Editura Corint Future, Bucureşti, 2019

Urs I.R., Duţu M., Severin A., Angheni S., Neculaescu S. (coord.), Enciclopedia furidică Română, vol. I, Editura Academiei Române şi Editura Universul Juridic, Bucureşti, 2018

Yeung K., Lodge M., Algorithmic Regulation, Editura Oxford University Press, 2019, ISBN 978-0-19-883849-4

Wacks R., Philosophy of Law, A Very Short Introduction, Ediţia a II-a, Editura Oxford University Press, Marea Britanie, 2014

Webb A., Cei nouă titani tech. Cum va schimba inteligenţa aritificială cursul omenirii, Editura Globo, Bucureşti, 2019

Wilks Y, Artificial Intelligence: Modern Magic or Dangerous Future?, Editura Icon Books Ltd., 2019 